\title{
Effect of direct adding oregano essential oil (Origanum syriacum L.) on quality and stability of chicken meat patties
}

\author{
Marwan AL-HIJAZEEN ${ }^{1 *}$
}

\begin{abstract}
Evaluate of Origanum syriacum L. essential oil grown in Jordan, and other comparable antioxidant on TBARS, total carbonyl, color values, and sensory attributes of raw chicken meat was investigated. Six treatments were prepared: (1) control (no additive); (2) $100 \mathrm{ppm}$ oregano essential oil (OE); (3) $150 \mathrm{ppm} \mathrm{OE;} \mathrm{(4)} 300 \mathrm{ppm} \mathrm{L-ascorbic} \mathrm{acid} \mathrm{(E-300);} \mathrm{(5)} 5$ and 14 ppm butylatedhydroxyanisole (BHA/E-320) for both breast and thigh meat respectively, and 6) $150 \mathrm{ppm}$ Sodium nitrite (E-250), were prepared using ground chicken meat. Generally, OE at level of $150 \mathrm{ppm}$ was the most effective decreasing TBARS, and total carbonyl values compared to the other treatments. Furthermore, it showed better color values ( $\mathrm{L}^{*}$ and $\mathrm{a}^{*}$ ) in term of meat color stability. However, OE and E-250 also showed the highest significant values among the other treatments. Sensory evaluation results showed that adding $\mathrm{OE}$ at level of $150 \mathrm{ppm}$ and $100 \mathrm{ppm}$ were the best values maintaining meat storage stability. Therefore, it can be recommended that $\mathrm{OE}$ at level of $150 \mathrm{ppm}$ could be an excellent replacement to the synthetic antioxidant in the future of uncured, natural fresh meat products, and raw meat prepared for processing.
\end{abstract}

Keywords: sensory attributes; lipid oxidation; oregano essential oil; protein oxidation.

Practical Application: Finding effective natural antioxidant as a replacement to the synthetic one to be used in meat preservation, enhance both organic and natural meat market, current consumer demands, and improve meat safety especially in meat processing industry.

\section{Introduction}

In meat processing, both manufactures and researchers are focusing toward using natural antioxidant (NA) instead of synthetic one (Solomakos et al., 2008; Shahidi, 2008; Karre et al., 2013). Several research studies reported that adding synthetic antioxidants (SA) may have negative effect on human health (Monahan \& Troy, 1997; Taghvaei \& Jafari, 2015). For example, In the United State of America (USA) they have been successfully used butylatedhydroxyanisole (BHA), butylatedhydroxytoluene (BHT), and tertiarybutylhydroquinone (TBHQ) to prevent oxidative changes in their meat products (Monahan \& Troy, 1997). However, these SA may have toxicological and carcinogenic effects on human (Altmann et al., 1986; Kumar et al., 2015). In addition sodium nitrite or sodium nitrate considers very essential preservative in meat processing (Zubillaga et al., 1984; Decker et al., 2010).

Recently, researchers were investigate finding a good combination with E-250 or decrease their residual amount in finished meat products by adding NA (Honikel, 2008; Oostindjer et al., 2014). However, they still need to study some method to manipulate the level of E-250 or their residual (Nitrite) in the finished meat products due to possibility of formation nitrosamines compounds (Sindelar \& Milkowski, 2011; Sebranek \& Bacus, 2007). Yet, natural and organic meat market where E-250 is not allowed, has been grown very fast (Natural-Uncured Meat Products) due to the recent consumer demands (Sebranek \& Bacus, 2007). Thus, we need to use NA such as L-ascorbic acid, and $\alpha$-Tocopherol, which already tested as meat preservative (Velasco \& Williams, 2011; Shebis et al., 2013).

In the last two decades, researchers tested medical plant extract like oregano, sage, rosemary, and grape seed (Economou et al., 1991; Yanishlieva \& Marinova, 1995; Man \& Jaswir, 2000) because they contain phenolic compounds which may increase or enhance shelf-life of foods. For example, oregano has been used for flavoring fish, meat and sauces since ancient times (Sahin et al., 2004). In the Middle East region where it grows widely, it has the common name of Zaatar and is usually collected for human consumption (Daouk et al., 1995).

L-Ascorbic acid (E-300) also used in meat processing industry due to their antioxidant activity (Nam \& Ahn, 2003). However, E-300 can: (1) accelerate color development and inhibit nitrosamine formation in cured meat, (2) prevent oxidation meat products (Izumi et al., 1989; Velasco \& Williams, 2011; Ismail et al., 2009). Usually meat color, and odor attributes are affecting primary consumer evaluation of meat quality or their overall acceptability (Liu et al., 1995; Mancini \& Hunt, 2005). Furthermore, lipid oxidation consider as the major internal problem affecting these attributes (Ahn et al., 2007; Nam et al., 2007) because it changes color, generate off-odor (Gray et al., 1996; Min et al., 2008; Ahn et al., 2009), and affect protein functionality (Hall, 1987). 
Therefore, NA such as OE could be good promising in the future of meat preservation (Al-Hijazeen et al., 2016a; Scramlin et al., 2010; Fasseas et al., 2007). Several research studies showed that the Origanum syriacum L var. syriacum. (Native of Jordan and Syria) has very strong antioxidant effect because of its major composition of thymol and carvacrol (Kokkini, 1997; Al-Bandak \& Oreopoulou, 2007) compared to the other Origanum species such as Origanum vulgare, Origanum onties, and Origanum majorana L. (Daouk, et al., 1995; Berna'th, 1997; Baser, 2002; Sahin et al., 2004). There were no research studies done before to evaluate the effect of direct adding Origanum syriacum L. grown in wild Jordan on poultry ground meat. However, different oil composition of these phenolic compounds may have different synergistic or additive effect compared to the other essential oils such as Origanum valgure (Brewer, 2011).

Thus the objective of this study were 1) to evaluate the effect of two level of Origanum syriacum L. essential oil on storage stability and quality characteristics of ground chicken meat during storage time and 2) to compare the antioxidant effect of Origanum syriacum $\mathrm{L}$. with the most popular antioxidant used in the meat industry.

\section{Materials and methods}

\subsection{Meat preparation}

Six week old of (140 birds) broilers fed basic diet were slaughtered at Mu'tah University (Agriculture Collage: Department of Animal Production-farm facilities). In addition this experiment was reviewed and approved by both Research Ethics Committee and Department of Animal Production, and all chicken were checked and veterinary being qualified for health and welfare. The chicken carcass were kept in water-ice mixture for $3 \mathrm{~h}$ and left in a cold condition, and the muscles were separated from the carcasses at $24 \mathrm{~h}$ after slaughter. Breast and thigh muscles were deboned, cleaned, skins removed, external fats trimmed off, vacuum packaged in oxygen impermeable bags, and stored at $-18^{\circ} \mathrm{C}$ freezer until used.

The frozen meats were thawed in the lab cooling area $\left(4^{\circ} \mathrm{C}\right)$, double ground using a $8-\mathrm{mm}$ and a $3-\mathrm{mm}$ plates (Moulinex, Type DKA1, France) to prepare the raw meat. Six different treatments including 1) (No additive), 2) $100 \mathrm{ppm} \mathrm{OE}, 3) 150 \mathrm{ppm} \mathrm{OE}$, 4) L-ascorbic acid (E-300), 5) 5 and 14ppm butylatedhydroxyanisole (BHA) for both breast and thigh meat, and 6) 150 ppm E-250 were prepared. The oregano essential oil was purchased from a local company in Jordan (Green Fields Factory for oils, Jordan). The HPLC analysis of the oregano essential oil (Royal Scientific Society, Jordan, Amman) indicated that $76.39 \%$ of the essential oil was carvacrol. L- ascorbic acid (Fisher Scientific, fair Lawn, N.J., USA), and sodium nitrite (Gainland Chemical company-GCC, factory road; UK) powder were dissolved in de-ionized distilled water (DDW) first, then oil emulsion (water in oil) using mineral oil were prepared to make their aqueous solution. BHA and OE were dissolved pure ethanol, and then mixed with mineral oil to make their stock solutions. The ethanol added was removed using a rotary evaporator (Heidolph, Model Laborota 4001-effecient) at $\left(70{ }^{\circ} \mathrm{C}, 175 \mathrm{mbar} \mathrm{Vp}\right)$ before mixing the stock solution to meat samples. Each additive was added to the ground breast or thigh meat and then mixed for $3 \mathrm{~min}$ in a bowl mixer (Model KM-331;
Kenwood Limited, New Lane, Havant, PO9 2NH, UK). All treatments were mixed with the same amounts of mineral oil and water (oil emulsion) to uniform the experiment condition.

Meat patties (100 g each) were individually packaged in oxygen-permeable bags (polyethylene, Size: 11 x $25 \mathrm{~cm}$, Future for Plastic Industry, Al-Moumtaz bags, Co. L.T.D, Jordan), stored at $4{ }^{\circ} \mathrm{C}$ cooler for up to 7 days, and analyzed for TBARS, total carbonyl, and color values at 0,4 , and 7 days of storage. Same preparation method was done for the sensory analysis and ground chicken breast patties were stored at $4{ }^{\circ} \mathrm{C}$ up to 4 days before each evaluation process.

\subsection{Thiobarbituric acid-reactive substances (TBARS) measurement}

Brefiley, the TBARS values in meat samples were measured according to the method described by Ahn et al. (1998). The TBARS values were calculated based on malonaldehyde (MDA) stander carve (TEP standard solution) and reported as $\mathrm{mg}$ of MDA per $\mathrm{kg}$ of meat.

\subsection{Protein oxidation (total carbonyl)}

Protein oxidation was determined by the method of Lund et al. (2008) with minor modifications as described by Al-Hijazeen et al. (2016a). In addition carbonyl content was recorded as $\mathrm{nmol} / \mathrm{mg}$ protein using absorption coefficient of $22,000 / \mathrm{M} / \mathrm{cm}$ as described by Levine et al. (1994).

\subsection{Color measurement}

The color was measured using a Konica Minolta Color Meter (CR-400, Konioca Minolta, Osaka, Japan). The colorimeter was calibrated using an illuminant source $\mathrm{C}$ on a standard white ceramic plate. The color were expressed as CIE $\mathrm{L}^{*}$ - (lightness), $\mathrm{a}^{*}$ - (redness), and $\mathrm{b}^{*}$ - (yellowness) values (American Meat Science Association, 1991). The obvious defects areas were avoided when reading the uniform color. An average two colorimeter measurement on each side of sample surface was used for data analysis.

\subsection{Trained sensory panels}

Line scales (hedonic scale) were used to evaluate the sensory attributes of the meat samples as described by Al-Hijazeen (2014). Ten trained panels were evaluated the color, aroma, and over all acceptability of raw ground meat samples. In addition, six different treatments were prepared with the same method described in the oxidation analysis part.

\subsection{Statistical analysis}

The procedure of generalized linear model (Proc. GLM, SAS program, SAS Institute Inc., version 9.3, 2012, Cary, NC, USA) (SAS Institute Inc., 2012) was used to analyze all experimental data. Mean values and standard error of the means (SEM) were reported. The significance was defined at $\mathrm{P}<0.05$ and Tukey test or Tukey's Multiple Range test were used to determine any significant differences between the mean values. 


\section{Results and discussion}

\subsection{Lipid oxidation}

Lipid oxidation consider major problem affecting quality and shelf life of fresh meat. It produces many volatile compounds causing off-odor, off-flavor, rancidity, and changing meat color. (Ahn et al., 1998; Guillén-Sans \& Guzmán-Chozas 1998; Ahn \& Lee, 2002; Byrne et al., 2002; Ahn \& Lee, 2002; Dietze et al., 2007; Campo et al., 2006). All treatments additives were showed no significant differences ( $\mathrm{p}>0.05$ ) on TBARS values of ground chicken meat during storage time (Table 1).

Oregano essential oil levels were selected depending on several preliminary studies on the oil antioxidant activity (Data were not shown). These results were agreed with Al-Hijazeen et al. (2016a) who reported that adding OE (Origanum vulgare subsp. hirtum) and BHA in ground chicken meat were very low and not significant $(\mathrm{P}>0.05)$ to each other due to the low amount of malondialdehyde formation in raw meat sample during storage time. In addition E-300 and E-250 were showed significant $(\mathrm{p}<0.05)$ antioxidant effect compared to the control samples (breast \& thigh meat) during storage time. All treatments additives were significantly $(\mathrm{p}<0.05)$ decrease TBARS values of ground chicken meat (breast \& thigh) after day 4 of storage time compared to the control samples. Among the treatments, $\mathrm{OE}$ at level of $150 \mathrm{ppm}$ showed the highest antioxidant effect during storage period. In addition L-ascorbic acid (E-300) TBARS values were the highest between the other treatments in this study. This agreed with Ismail et al. (2009) who suggested that the effectiveness of ascorbic acid decrease as storage time increase when testing TBARS values in ground beef sample. However, E-250 at level 150 ppm and the OE (150 ppm) TBARS values were very close and have the highest antioxidant effect among the other treatments. The antioxidant activity of oregano oil generated from their high content of cravacrol and thymol. Part of the additive nitrite is oxidized to nitrate by sequestering oxygen in meat emulsion, and some of nitrate may be reduced to nitrite in raw meat by microorganisms (Honikel, 2008). In addition it is clearly known that nitrite has the ability to be effective delaying oxidative rancidity development (Sindelar \& Milkowski, 2011). Furthermore, the data showed that we don't have higher significances between these treatments especially when use raw meat samples. The TBARS values usually in the raw chicken meat are considered very low, and the significances could be better if cooked meat used (Min et al., 2008; Ahn et al., 2009). This may be due to the low free iron content and high ferric ion reducing capacity in fresh meat (Min et al., 2008). Similar trend where found by Chouliara et al. (2007) who added $0.1 \%$ of oregano oil in fresh chicken breast meat, and Kim et al. (2002) who use the raw turkey meat. Finally, there were no significant differences $(p>0.05)$ between the two OE levels using the raw (breast \& thigh) meat samples.

\subsection{Protein oxidation}

Carbonylation is considered as one of the most remarkable chemical changes during protein oxidation (Estevez, 2011; Soliga et al., 2016). In addition it is important factor that can cause changes in meat quality (Soladoye et al., 2015). In addition, protein is induced by several free radical species such as hydroxyl radicals, peroxyl and alkoxyl radicals as well as superoxide anions, and hydrogen peroxide (Lawrie, 1998; Ouali et al., 2006; Hopkins \& Geesink, 2009). In all raw meat samples (breast \& thigh) there were no significant differences $(p>0.05)$ between all treatments at day 0 of storage time (Table 2 ).

Furthermore, no significant differences $(\mathrm{P}>0.05)$ were found among all treatments using breast meat samples at day 4 of storage time. This was agreed with Al-Hijazeen et al. (2016a, b) where the total carbonyl values were very low and not enough to exhibit the significances. In general total estimated carbonyl contents arranged in 1-3 nmol/mg protein for raw meat (Estevez, 2011). On the other hand, there were a wide variability of total carbonyl values depending on the muscle fiber type, experimental condition, animal species, and the laboratory analysis method (Soliga et al., 2016). However, for all treatments additives total carbonyl values were significantly $(\mathrm{p}<0.05)$ delayed using both breast and thigh meat at day 7 of storage time compared to the control. Oregano essential oil (150 ppm) and E-250 also showed similar trend as lipid oxidation effect, where it showed the lowest values of total carbonyl compared to the other. Furthermore, E-300 and BHA additives also showed higher carbonyl values

Table 1. TBARS value of raw ground chicken patties added with different levels of oregano oil during refrigerated storage at $4{ }^{\circ} \mathrm{C}$.

\begin{tabular}{|c|c|c|c|c|c|c|c|}
\hline Time & $\begin{array}{l}\text { Control } \\
\text { without }\end{array}$ & $\begin{array}{l}100 \text { PPM } \\
\text { Oregano }\end{array}$ & $\begin{array}{l}150 \mathrm{PPM} \\
\text { Oregano }\end{array}$ & $\begin{array}{c}300 \text { PPM } \\
\text { E-300 }\end{array}$ & $\begin{array}{c}\text { 5/14 PPM } \\
\text { BHA }\end{array}$ & $\begin{array}{c}\text { NO } \\
150 \text { PPM }\end{array}$ & SEM \\
\hline \multicolumn{8}{|l|}{ Breast } \\
\hline Day 4 & $0.174^{\text {ay }}$ & $0.142^{b x}$ & $0.122^{\text {bxy }}$ & $0.139^{\text {bx }}$ & $0.132^{\text {bx }}$ & $0.122^{\mathrm{bx}}$ & 0.006 \\
\hline Day 7 & $0.232^{\mathrm{ax}}$ & $0.154^{\text {bx }}$ & $0.131^{\mathrm{bx}}$ & $0.148^{\mathrm{bx}}$ & $0.137^{\mathrm{bx}}$ & $0.136^{b x}$ & 0.006 \\
\hline Day 0 & $0.21^{\mathrm{az}}$ & $0.19^{\text {ay }}$ & $0.20^{\text {ay }}$ & $0.21^{\text {ay }}$ & $0.20^{\mathrm{ay}}$ & $0.20^{\text {ay }}$ & 0.022 \\
\hline Day 4 & $1.06^{\mathrm{ay}}$ & $0.32^{\text {by }}$ & $0.26^{\text {by }}$ & $0.33^{\text {by }}$ & $0.26^{\text {by }}$ & $0.26^{\text {by }}$ & 0.027 \\
\hline Day 7 & $2.46^{\mathrm{ax}}$ & $0.95^{\mathrm{bx}}$ & $0.71^{\mathrm{bx}}$ & $0.97^{\mathrm{bx}}$ & $0.85^{\text {bx }}$ & $0.80^{\mathrm{bx}}$ & 0.084 \\
\hline SEM & 0.074 & 0.052 & 0.069 & 0.032 & 0.023 & 0.045 & \\
\hline
\end{tabular}

${ }^{\mathrm{a}-\mathrm{c}}$ Values with different letter within a row are significantly different $(\mathrm{P}<0.05)$; ${ }^{\mathrm{x}-\mathrm{z}}$-Values with different letters within a column are significantly different $(\mathrm{P}<0.05)$. Treatments: Control;

100 ppm Oregano oil; 150 ppm Oregano oil; 300 ppm Ascorbic acid; 5 and 14 ppm BHA for breast and thigh respectively; 150 ppm Sodium Nitrite. N=4. 
Table 2. Effect of adding different level of oregano oil on total carbonyl of raw ground chicken meat at different storage time.

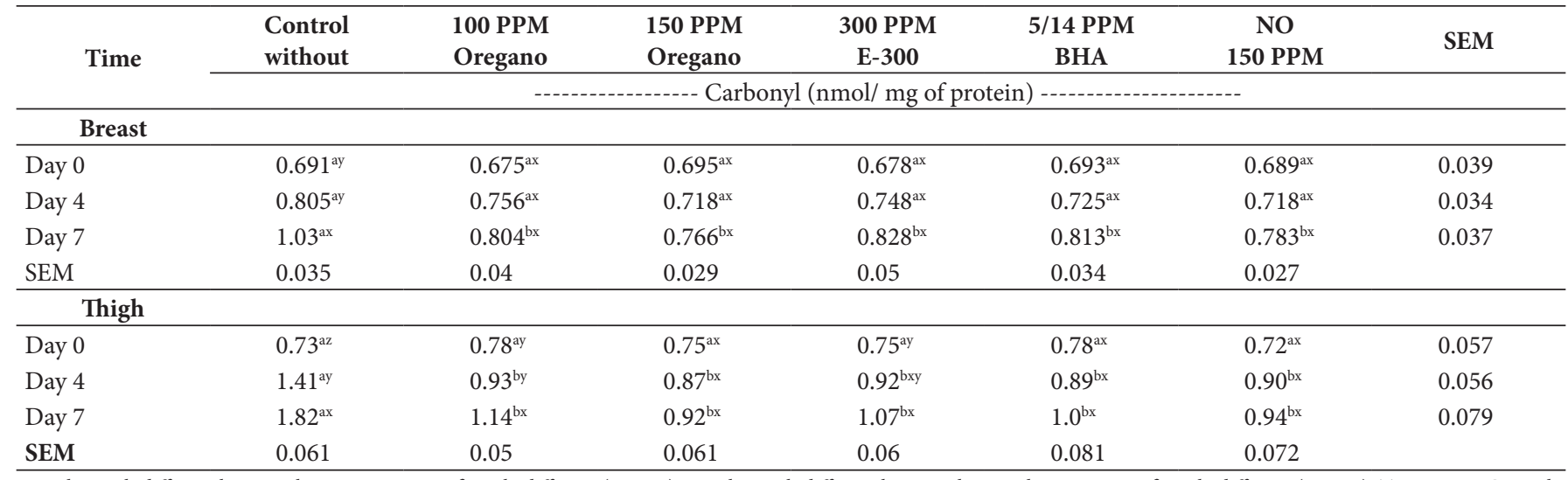

${ }^{\mathrm{a}-\mathrm{c}-}$ Value with different letter within a row are significantly different $(\mathrm{P}<0.05) ;{ }^{\mathrm{x}-\mathrm{z}-}$ Value with different letter within a column are significantly different $(\mathrm{p}<0.05)$. Treatments: Control; 100 ppm Oregano oil; 150 ppm Oregano oil; 300 ppm Ascorbic acid; 5(breast) and 14(thigh) ppm BHA; 150 ppm Sodium Nitrite. N = 4 .

compared to E-250 and oregano oil (150ppm) treatments. There were no significant difference $(\mathrm{P}>0.05)$ between $\mathrm{OE}$ treatments (100 ppm and $150 \mathrm{ppm})$ using the raw meat samples. This level (150 ppm) oregano essential oil (Origanum syriacum L.) was more effective than the Origanum vulgare oil tested by Al-Hijazeen et al. (2016a) previously. The differences in the antioxidant effect of these essential oils may be due to their different content and amount of polyphenol compounds (Brewer, 2011).

\subsection{Meat color}

Visual meat color depends on many factors can change overall consumer final decision (Suman \& Joseph, 2013). For example, myoglobin pigment concentration, $\mathrm{pH}$ decline, muscle fiber type, and many other post and ante-mortem factors may affect meat discoloration (Faustman \& Cassens, 1990; Suman \& Joseph, 2013; Calnan et al., 2014). At day 0 of storage time there were no significant differences $(P>0.05)$ among all treatments additives of the lightness ( $\mathrm{L}^{*}$-values), redness ( $\mathrm{a}^{*}$-values), and blueness ( $b^{*}$-values). Using ground chicken meat there were no significant differences $(P>0.05)$ between $L^{*}$ values until day 4 of storage time (Table 3 ). In addition OE treatments were showed significant effect $(\mathrm{P}<0.05)$ compared to the control samples at day 7 of storage time on $L^{*}$ values using breast meat. Furthermore, the lightness ( $L^{*}$-values) were significantly $(\mathrm{P}<0.05)$ decreased during storage time. This was in agreement with the result reported by Al-Hijazeen et al. (2016a), who use different treatments additives and they found similar trend in $\mathrm{L}^{*}$ values change until day 3 in his study. However $\mathrm{OE}$ treatments were showed highest effect on stabilizing $L^{\star}$ values compared to the other treatments at day 7 of storage time. At day four of storage time $\mathrm{a}^{*}$ values were decreased significantly $(\mathrm{P}<0.05)$ compared to day 0 . These result of $\mathrm{a}^{*}$ values were very similar to Al-Hijazeen et al. (2016, a, b) who use ground chicken meat in his study for both oregano and tannic acid effect studies. This may be due to lower content of myglobin pigment $(0.05 \mathrm{mg} / \mathrm{g})$, and low free heme iron in the chicken breast meat.

It was clearly that the highest $\mathrm{a}^{*}$-value was appeared using $\mathrm{OE}$ at level of $150 \mathrm{ppm}$ compared to the other treatments at day
7 of storage time (Table 3 ). In addition there were no significant differences $(\mathrm{P}>0.05)$ on $\mathrm{b}^{*}$ values for all treatments additives at day 0 and 7 (inconsistent change) using breast meat. In thigh meat samples the OE at level $150 \mathrm{ppm}$ shows the highest storage stability effect on $\mathrm{L}^{*}$ and $\mathrm{a}^{*}$ values compared to the other treatments. This effect on meat color stability was similar to several other researchers testing OE (Fasseas et al., 2007; Vital et al., 2016). The color stability effect was more importance and clearer using thigh meat due to the higher myoglobin content in thigh compared to the breast meat (Table 3). Although there were no significance differences $(\mathrm{P}>0.05)$ between treatments additive (antioxidants) values of ( $\mathrm{a}^{\star}$-values) the $\mathrm{OE}$ shows the highest effect maintaining color stability.

\subsection{Sensory evaluation}

Using breast meat samples there were significant differences $(p<0.05)$ of all treatment compared to the control on redness, oxidation odor, and the overall acceptability attributes. Redness or the visual red color attributes was not significant $(\mathrm{P}>0.05)$ between all treatments additives. This may be due to the low content of oxymyoglobin pigment in breast meat samples compared to the thigh meat. Oregano odor was very clear and highly significant $(\mathrm{p}<0.05)$ in all samples with adding OE compared to the other treatments (Table 4).

Thus, Oxidation odor was the lowest using the OE treatments additives. Finally, mean value of the overall acceptability showed that the control sample was the lowest, and the best values were appear when using oregano oil and sodium nitrite. This was in agreement with the lipid, protein, and color values measured previously. These results were agreed with Al-Hijazeen et al. (2016a) who study the effect of adding different level of oregano oil (Origanum vulgare) on sensory attributes of both raw and cooked chicken meat. Generally adding herbal plant extract or their essential oils was extensively studied and showed positive effect on the overall meat quality and visual properties such as color and aroma (Kahraman et al., 2015; Vital et al., 2016). 
Table 3. CIE Color value of ground chicken meat patties with different level of oregano oil during storage at $4^{\circ} \mathrm{C}$.

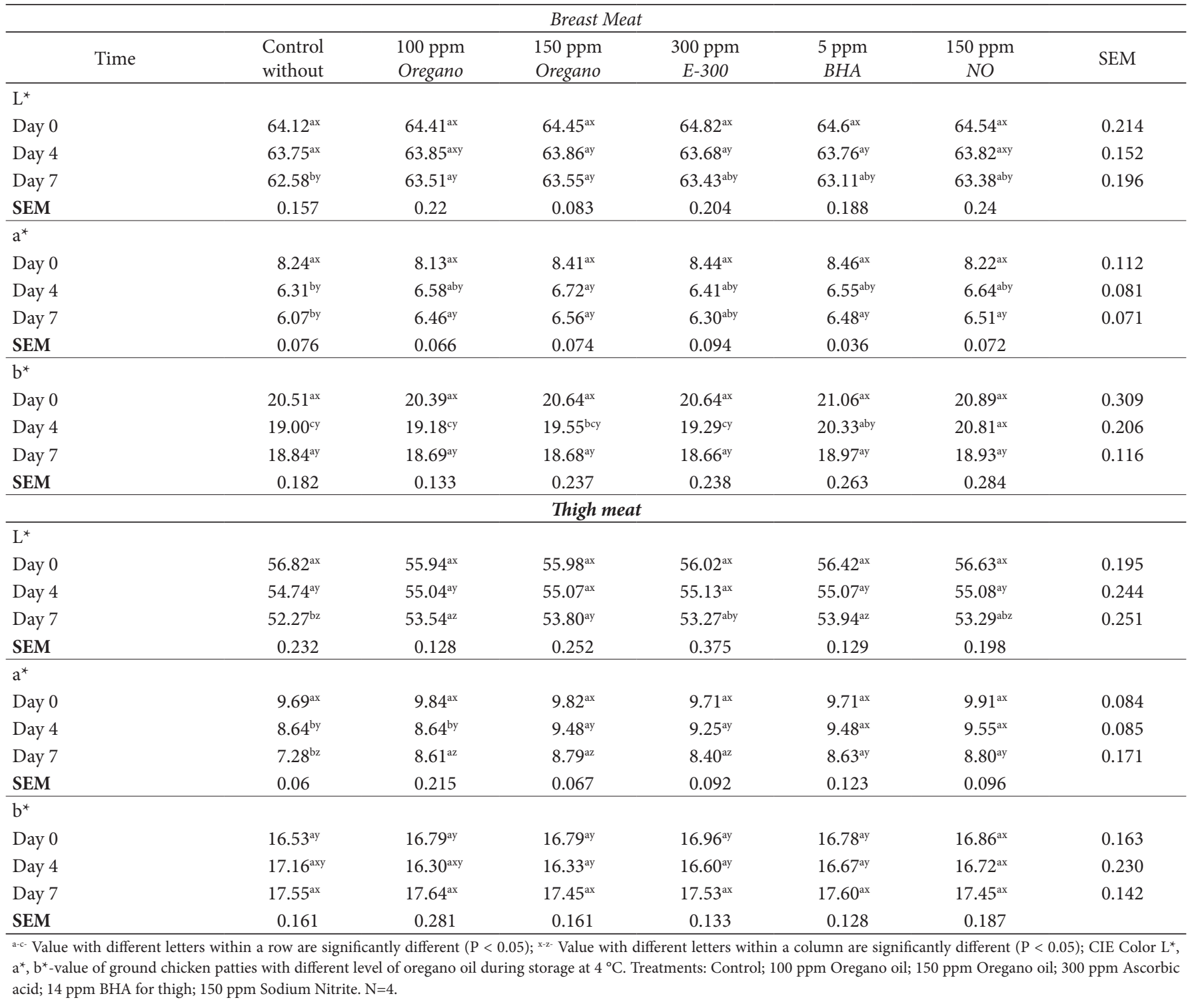

Table 4. Sensory attributes means of raw ground chicken breast meat patties.

\begin{tabular}{ccccc}
\hline \multicolumn{5}{c}{ Sensory attributes $^{\mathrm{b}}$} \\
\hline TRT $^{*}$ & Redness Color & Oregano Odor & Oxidation Odor & Over All Acceptability \\
\hline T1 & $5.85^{\mathrm{b}}$ & $0.72^{\mathrm{c}}$ & $4.33^{\mathrm{a}}$ & $3.30^{\mathrm{c}}$ \\
T2 & $7.63^{\mathrm{a}}$ & $6.31^{\mathrm{a}}$ & $2.77^{\mathrm{b}}$ & $6.50^{\mathrm{ab}}$ \\
T3 & $5.17^{\mathrm{a}}$ & $6.73^{\mathrm{a}}$ & $1.61^{\mathrm{b}}$ & $7.21^{\mathrm{a}}$ \\
T4 & $7.39^{\mathrm{a}}$ & $0.86^{\mathrm{c}}$ & $2.94^{\mathrm{b}}$ & $6.05^{\mathrm{b}}$ \\
T5 & $8.03^{\mathrm{a}}$ & $1.74^{\mathrm{b}}$ & $2.13^{\mathrm{b}}$ & $6.67^{\mathrm{ab}}$ \\
T6 & $7.09^{\mathrm{a}}$ & $1.23^{\mathrm{bc}}$ & $1.74^{\mathrm{b}}$ & $6.94^{\mathrm{ab}}$ \\
SEM $^{\mathrm{c}}$ & 0.261 & 0.195 & 0.326 & 0.227 \\
\hline
\end{tabular}

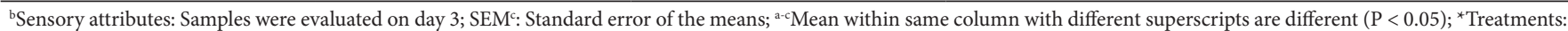
T1: Control; T2:100 ppm Oregano oil; T3:150 ppm Oregano oil; T4:300 ppm Ascorbic acid; T5: 5 ppm BHA; T6: 150 ppm Sodium Nitrite. N=10.

\section{Conclusions}

Oregano essential oil (Origanum Syriacum L.) at level of $150 \mathrm{ppm}$ was very effective delaying lipid and protein oxidation. In addition it showed better color values $\left(\mathrm{L}^{\star} \& \mathrm{a}^{*}\right)$ in term of meat color stability. However, OE (150ppm) and E-250 also showed the highest significant $(\mathrm{P}<0.05)$ effect of all previous parameters. BHA, and E-300 were showed remarkable antioxidant effect but it was the lowest compared to the other additives 
using TBARS and total carbonyl values. From the sensory evaluation results we can suggest that adding OE (150 ppm) was prospective antioxidant could be added to maintain meat storage stability. In general $\mathrm{OE}$ at level of $150 \mathrm{ppm}$ could be an excellent antioxidant replacement or partially substitution in the future of uncured and natural fresh meat products.

\section{Acknowledgements}

This study was financially supported by the Deanship of Scientific Research at Mu'tah University, Al-karak, Jordan. Grant number: 120/14/118 (2015). This funding is highly appreciated with my deep thankful to all other Animal Science Department stuff on their help and advices.

\section{References}

Ahn, D. U., \& Lee, E. J. (2002). Production of off-odor volatiles from liposome-containing amino acid homopolymers by irradiation. Journal of Food Science, 67(7), 2659-2665. http://dx.doi. org/10.1111/j.1365-2621.2002.tb08795.x.

Ahn, D. U., Nam, K. C., \& Lee, E. J. (2009). Lipid oxidation and flavor. In M. Du \& R. J. McCormick (Eds.), Applied muscle biology and meat science (Chap. 12, pp. 227-246). Baco Raton: CRC Press, Taylor and Francis Group.

Ahn, D. U., Olson, D. G., Jo, C., Chen, X., Wu, C., \& Lee, J. I. (1998). Effect of muscle type, packaging, and irradiation on lipid oxidation, volatile production and color in raw pork patties. Meat Science, 49, 27-39. PMid: 22063182. https://dx.doi.org/ 10.1016/S03091740(97)00101-0.

Ahn, J., Grun, I. U., \& Mustapha, A. (2007). Effect of plant extracts on microbial growth, colour change, and lipid oxidation in cooked beef. Food Microbiology, 24(1), 7-14. PMid:16943089. http://dx.doi. org/10.1016/j.fm.2006.04.006.

Al-Bandak, G., \& Oreopoulou, V. (2007). Antioxidant properties and composition of Majorana syriaca extracts. European Journal of Lipid Science and Technology, 109, 247-255. http://dx.doi.org/10.1002/ ejlt.200600234.

Al-Hijazeen, M. (2014). Effect of oregano essential oil and tannic acid on storage stability and quality of ground chicken meat (Ph.D. thesis). Iowa State University, Ames. Retrieved from http://lib.dr.iastate. edu/cgi/viewcontent.cgi? article $=4973 \&$ context $=$ etd

Al-Hijazeen, M., Lee, E. J., Mendonca, A., \& Ahn, D. U. K. (2016a). Effect of oregano essential oil (Origanum vulgare subsp. hirtum) on the storage stability and quality parameters of ground chicken breast meat. Antioxidants, 5(2), pii-E18, PMid: 27338486. https:// dx.doi.org/ 10.3390/antiox5020018.

Al-Hijazeen, M., Lee, E. J., Mendonca, A., \& Ahn, D. U. K. (2016b). Effects of tannic acid on lipid and protein oxidation, color, and volatiles of raw and cooked chicken breast meat during storage. Antioxidants, 5(2), pii-E19. PMid: 27304971. https://dx.doi. org/10.3390/antiox 5020019.

Altmann, H. J., Grunow, W., Mohr, U., Richter-Reichhelm, H. B., \& Wester, P. W. (1986). Effects of BHA and related phenols on the forestomach of rats. Food and Chemical Toxicology, 24(10-11), 11831188. PMid:3804120. http://dx.doi.org/10.1016/0278-6915(86)90306-6.

American Meat Science Association - AMSA. (1991). Guideline for meat color evaluation. In Proceedings of the 4th Reciprocal Meat Conference. Chicago, IL.
Baser, H. (2002). Aromatic biodiversity among the flowering plant taxa of Turkey. Pure and Applied Chemistry, 74(4), 527-545. http:// dx.doi.org/10.1351/pac200274040527.

Berna'th, J. (1997). Some scientific and practical aspects of production and utilization of oregano in central Europe. In Proceedings of the IPGRI International Workshop on Oregano, Valenzano, Bari, Italy. Retrieved from https://eurekamag. com/research/003/276/003276631.php

Brewer, M. S. (2011). Natural Antioxidants: sources, compounds, mechanisms of action, and potential applications. Comprehensive Reviews in Food Science and Food Safety, 10(4), 221-247. http:// dx.doi.org/10.1111/j.1541-4337.2011.00156.x.

Byrne, D. V., Bredie, W. L., Mottram, D. S., \& Martens, M. (2002). Sensory and chemical investigations on the effect of oven cooking on warmed-over flavor development in chicken meat. Meat Science, 61, 127-139. https://dx.doi.org/10.1016/S0309-1740(01)00171-1.

Calnan, H. B., Jacob, R. H., Pethick, D. W., \& Gardner, G. E. (2014). Factor affecting the colour of lamb meat from the longissimus muscle during display: the influence of muscle weight and muscle oxidative capacity. Meat Science, 96(2 Pt B), 1049-1057. PMid:24080243. http://dx.doi.org/10.1016/j.meatsci.2013.08.032.

Campo, M. M., Nute, G. R., Hughes, S. I., Enser, M., Wood, J. D., \& Richardson, R. I. (2006). Flavour perception of oxidation in beef. Meat Science, 72(2), 303-311. PMid:22061558. http://dx.doi. org/10.1016/j.meatsci.2005.07.015.

Chouliara, E., Karatapanis, A., Savvaidis, I. N., \& Kontominas, M. G. (2007). Combined effect of oregano essential oil and modified atmosphere packaging on shelf-life extension of fresh chicken breast meat, stored at 4 degrees C. Food Microbiology, 24(6), 607617. PMid:17418312. http://dx.doi.org/10.1016/j.fm.2006.12.005.

Daouk, R., Dagher, S. M., \& Sattout, E. (1995). Antifungal activity of the essential of Origanum syriacum L. Journal of Food Protection, 58(10), 1147-1149. http://dx.doi.org/10.4315/0362-028X-58.10.1147.

Decker, E. A., Elias, R. J., \& McCkements, D. J. (2010). Addition of nitrites and nitrates (Vol. 2, Management in different industry sectors, pp. 74). In E. A. Decker, R. J. Elias, \& D. J. McCkements (Eds.), Oxidation in foods and beverages and antioxidant applications. Cambridge: Woodhead Publishing Limited.

Dietze, K., Lammers, M., \& Ternes, W. (2007). Effect of natural additive on warmed-over flavor of dark turkey meat analyzed with dynamic headspace GC/MS. Fleischwirtsch Int, 23(5), 67-70.

Economou, K. D., Oreopoulou, V., \& Thomopouls, C. D. (1991). Antioxidant properties of some plant extract of the labiatate family. Journal of the American Oil Chemists' Society, 68(2), 109-113. http:// dx.doi.org/10.1007/BF02662329.

Estevez, M. (2011). Protein carbonyls in meat system: a review. Meat Science, 89(3), 259-279. PMid:21621336. http://dx.doi.org/10.1016/j. meatsci.2011.04.025.

Fasseas, M. K., Mountzouris, K. C., Tarantilis, P. A., Polissiou, M., \& Zervas, G. (2007). Antioxidant activity in meat treated with oregano and sage essential oils. Food Chemistry, 106(3), 1188-1194. http:// dx.doi.org/10.1016/j.foodchem.2007.07.060.

Faustman, C., \& Cassens, R. G. (1990). The biochemical basis for discoloration in fresh meat: a review. Journal of Muscle Foods, 1, 217-243. https://dx.doi.org/10.1111/j.1745-4573.1990.tb00366.x.

Gray, J. I., Gomaa, E. A., \& Buckley, D. J. (1996). Oxidative quality and shelf life of meats. Meat Science, 43, S111-S123. PMid:22060645. http://dx.doi.org/10.1016/0309-1740(96)00059-9.

Guillén-Sans, R., \& Guzmán-Chozas, M. (1998). The thiobarbibutric acid (TBA) reaction in food: a review. Critical Reviews in Food 
Science and Nutrition, 38(4), 315-330. PMid:9626489. http://dx.doi. org/10.1080/10408699891274228.

Hall, G. (1987). Interactions between products of lipid oxidation and proteins. Food Science and Technology, 1, 155-158.

Honikel, K. O. (2008). The use and control of nitrate and nitrite for the processing of meat products. Meat Science, 78:68-76. PMid: 22062097. https://dx.doi.org/ 10.1016/j.meatsci.2007.05.030.

Hopkins, D. L., \& Geesink, G. H. (2009). Protein degradation postmortem and tenderization. In M. Du \& R. J. McCormick (Eds.), Applied muscle biology and meat science (pp. 149-166). Boca Raton: CRC Press, Taylor \& Francis Group.

Ismail, H. A., Lee, E. J., Ko, K. Y., Paik, H. D., \& Ahn, D. U. (2009). Effect of antioxidant application methods on color, lipid oxidation, and volatiles of irradiated ground beef. Journal of Food Science, 74(1), C25-C32. PMid:19200082. http://dx.doi.org/10.1111/j.17503841.2008.00991.x.

Izumi, K., Gassens, R. G., \& Greaser, M. L. (1989). Reaction of nitrite with ascorbic acid and its significant role in nitrite-cured food. Meat Science, 26(2), 141-153. PMid: 22054846. https://dx.doi. org/10.1016/0309-1740(89)90037-5.

Kahraman, T., Issa, G., Bingol, E. V., \& Kahraman, E. M. (2015). Effect of rosemary essential oil and modified-atmosphere packaging (MAD) on meat quality and survival of pathogens in poultry fillets. Brazilian Journal of Microbiology, 46(2), 591-599. http://dx.doi.org/10.1590/ S1517-838246220131201.

Karre, L., Lopez, K., \& Getty, K. J. K. (2013). Natural antioxidant in meat and poultry products. Meat Science, 94(2), 220-227. PMid:23501254. http://dx.doi.org/10.1016/j.meatsci.2013.01.007.

Kim, Y. H., Nam, K. C., \& Ahn, D. U. (2002). Volatile profiles, lipid oxidation and sensory characteristics of irradiated meat from different animal species. Meat Science, 61, 257-265. PMid: 22060848. http:// dx.doi.org/10.1016/S0309-1740(01)00191-7.

Kokkini, S. (1997). Taxonomy, diversity, and distribution of origanum species. In S. Padulosi (Ed.), Proceedings of the IPGRI international workshop on Oregano, Valenzano, Bari, Italy.

Kumar, Y., Yadav, D. N., Aham, T., \& Narsaiah, K. (2015). Recent trend in the use of natural antioxidants for meat and meat products. Comprehensive Reviews in Food Science and Food Safety, 14, 796812. https://dx.doi.org/10.1111/1541-4337.12156.

Lawrie, R. A. (1998). Chemical and biological constitution of muscle. In R. A. Lawrie. Meat science (6th ed., pp. 58-63). Boca Raton: CRC Press.

Levine, R. L., Williams, J. A. Stadtman, E. R., \& Shacter, E. (1994). Carbonyl assays for determination of oxidatively modified proteins. Methods Enzymology, 233, 346-357. PMid: 8015469. http://dx.doi. org/10.1016/S0076-6879(94)33040-9.

Liu, Q., Lanari, M. C., \& Schaefer, D. M. (1995). A review of dietary vitamin E supplementation for improvement of beef quality. Journal of Animal Science, 73(10), 3131-3140. PMid:8617686. http://dx.doi. org/10.2527/1995.73103131x.

Lund, M. N., Hviid, M. S., Claudi-Magnussen, C., \& Skibsted, L. H. (2008). Effects of dietary soybean oil on lipid and protein oxidation in pork patties during chill storage. Meat Science, 79(4), 727-733. PMid:22063036. http://dx.doi.org/10.1016/j.meatsci.2007.11.008.

Man, Y., \& Jaswir, I. (2000). Effect of rosemary and sage extracts on frying performance of refind, bleached and deodorized plam olein during deep-fat frying. Food Chemistry, 69, 301-307. https://doi. org/10.1016/S0308-8146(99)00270-8.

Mancini, R. A., \& Hunt, M. C. (2005). Current research in meat color. Meat Science, 71(1), 100-121. PMid:22064056. http://dx.doi. org/10.1016/j.meatsci.2005.03.003.
Min, B., Nam, K. C., Cordray, J., \& Ahn, D. U. (2008). Endogenous factors affecting oxidative stability of beef loin, pork loin, and chicken breast and thigh meats. Journal of Food Science, 73(6), C439-C446. PMid:19241532. http://dx.doi.org/10.1111/j.1750-3841.2008.00805.x.

Monahan, F. J., \& Troy, D. J. (1997). Overcoming sensory problems in low fat and low salt products. In A. M. Pearson \& T. R. Dutson (Eds.), Advances in meat research, production and processing of healthy meat, poultry and fish products (Chap. 11, pp. 257-281). London: Blackie Academic and Professional.

Nam, K. C., Ko, K. Y., Min, B. R., Ismail, H., Lee, E. J., Cordray, J., \& Ahn, D. U. (2007). Effect of oleoresin-tocopherol combinations on lipid oxidation, off-odor, and color of irradiated raw and cooked pork patties. Meat Science, 75(1), 61-70. PMid:22063412. http:// dx.doi.org/10.1016/j.meatsci.2006.06.016.

Nam, K., \& Ahn, D. U. (2003). Effect of ascorbic acid and antioxidants on the color of irradiated ground beef. Journal of Food Science, 68(5), 1686-1690. http://dx.doi.org/10.1111/j.1365-2621.2003.tb12314.x.

Oostindjer, M., Alexander, J., Amdam, G. V., Andersen, G., Bryan, N. S., Chen, D., Corpet, D. E., De Smet, S., Dragsted, L. O., Haug, A., Karlsson, A. H., Kleter, G., de Kok, T. M., Kulseng, B., Milkowski, A. L., Martin, R. J., Pajari, A.-M., Paulsen, J. E., Pickova, J., Rudi, K., Sødring, M., Weed, D. L., \& Egelandsdal, B. (2014). The role of red and processed meat in colorectal cancer development: a perspective. Meat Science, 97(4), 583-596. PMid:24769880. http:// dx.doi.org/10.1016/j.meatsci.2014.02.011.

Ouali, A., Herrera-Mendez, C., Coulis, G., Becula, A., Boudjellal, A., Aubry, L., \& Sentanderu, M. A. (2006). Revisiting the conversion of muscle into meat and the underelying mechanisms. Meat Science, 74, 44-58. PMid: 22062715. http://dx.doi.org/10.1016/j. meatsci.2006.05.010.

Sahin, F., Gcullcuce, M., Daferera, D., Scokmen, A., Scokmen, M., Polissiou, M., Agar, G., \& Özer, H. (2004). Biological activities of the essential oils and methanol extract of Origanum vulgare ssp. vulgare in the Eastern Anatolia region of Turkey. Journal of the Science of Food and Agriculture, 15, 549-557. http://dx.doi.org/10.1002/jsfa.1728.

SAS Institute Inc. (2012). Base SAS 9.3 Procedures Guide. Cary, NC: SAS Institute Inc.

Scramlin, S. M., Newman, R. B., Cox, R. B., Sepe, H. A., Alderton, A. L., O'Leary, J., \& Mikel, W. (2010). Effects of oregano oil brine enhancement on quality attributes of beef Longissimus dorsi and Semimbranosus muscles from various age animals. Journal of Food Science, 75(2), S89-S94. PMid:20492261. http://dx.doi.org/10.1111/ j.1750-3841.2009.01459.x.

Sebranek, G. J., \& Bacus, J. N. (2007). Cured meat products without direct addition of nitrate or nitrite. Meat Science, 77(1), 136-147. PMid: 22061404. http://dx.doi.org 10.1016/j.meatsci.2007.03.025.

Shahidi, F. (2008). Antioxidants: extraction, identification, application and efficacy measurement. Electronic Journal of Environmental, Agricultural and Food Chemistry, 8, 3325-3330.

Shebis, Y., Iluz, D., Tahan, Y. K., Dubinsky, Z., \& Yehoshua, Y. (2013). Natural antioxidants: function and sources. Food and Nutrition Sciences, 4(6), 643-649. http://dx.doi.org/10.4236/fns.2013.46083.

Sindelar, J. J., \& Milkowski, A. L. (2011). Sodium nitrite in processed meat and poultry meats: a review of curing and examining the risk/benefit of its use. Champaign: American Meat Science Association. Retrieved from http://www.meatscience.org/SodiumNitriteReview.aspx.

Soladoye, O.P., Juarez, M.L., Aalhus, J. L., Shand, P., \& Eztevez, M. (2015). Protein oxidation in processed meat: mechanisms and potential implications on human health. Comprehensive Reviews in Food Science and Food safety, 14, 106-122. http://dx.doi.org/ 10.1111/1541-4337.12127. 
Soliga, F., Petracci, M., \& Ertbjerg, P. (2016). Novel DNPH-based method for determination of protein carbonylation in muscle and meat. Food Chemistry, 197(Pt A), 670-675. PMid: 26617002. http:// dx.doi.org/10.1016/j.foodchem.2015.11.038.

Solomakos, N., Govaris, A., Koidis, P., \& Botsoglou, N. (2008). The antimicrobial effect of thyme essential oil, nisin and their combination against Escherichia coli O157:H7 in minced beef during refrigerated storage. Meat Science, 80(2), 159-166. PMid:22063318. http://dx.doi. org/10.1016/j.meatsci.2007.11.014.

Suman, S. P., \& Joseph, P. (2013). Myoglobin chemistry and meat color. Annual Review of Food Science and Technology, 4(1), 79-99. PMid:23190143. http://dx.doi.org/10.1146/annurev-food-030212-182623.

Taghvaei, M., \& Jafari, S. M. (2015). Application and stability of natural antioxidants in edible oils in order to substitute synthetic additives. Journal of Food Science and Technology, 52(3), 1272-1282. PMid:25745196. http://dx.doi.org/10.1007/s13197-013-1080-1.
Velasco, V., \& Williams, P. (2011). Improving meat quality through natural antioxidants. Chilean Journal of Agricultural Research, 71(2), 313-322. http://dx.doi.org/10.4067/S0718-58392011000200017.

Vital, A. C., Guerrero, A., Monteschio, J. O., Valero, M. V., Carvalho, C. B., Abreu, B. A. Fo., Madrona, G. S., \& Prado, I. N. (2016). Effect of edible and active coating (with rosemary and oregano essential oils) on beef characteristics and consumer acceptability. PLoS One, 11(8), e0160535. PMid:27504957. http://dx.doi.org/10.1371/journal. pone. 0160535 .

Yanishlieva, V., \& Marinova, M. (1995). Antioxidant activity of selected species of the family Lamiaceae grown in Bulgaria. Molecular Nutrition \& Food Research, 39, 458-463. http://dx.doi.org/10.1002/ food.19950390510.

Zubillaga, M. P., Maerker, G., \& Foglia, T. A. (1984). Antioxidant activity of sodium nitrite in meat. Journal of the American Oil Chemists Society, 61(4), 772-776. http://dx.doi.org/10.1007/BF02672133. 